\title{
THE INFLUENCE OF SINGLE AND COMBINED EFFECTS OF $Z n$, Cu AND TEMPERATURE ON MICROBIAL GROWTH
}

\author{
ŞENGÖR S.S. ${ }^{1}$ \\ GIKAS P. ${ }^{2, *}$
}

\author{
${ }^{1}$ Southern Methodist University \\ Department of Civil and Environmental Engineering \\ Dallas, TX 75205, USA \\ ${ }^{2}$ Technical University of Crete \\ School of Environmental Engineering \\ Chania, Greece
}

Received: 20/06/2012

Accepted: 30/04/2014

*to whom all correspondence should be addressed: e-mail: petros.gikas@enveng.tuc.gr

ABSTRACT

The purpose of the present study is to investigate the single and joint effect of zinc and copper to the growth pattern of the metal tolerant species of Arthrobacter sp. JM018. The results showed that, both, $\mathrm{Zn}$ and $\mathrm{Cu}$ at concentrations between 1 to $10 \mu \mathrm{M}$ stimulated the growth of the above microorganism at $35^{\circ} \mathrm{C}$. Stimulation was reduced with the increase of $\mathrm{Zn}$ concentration, while the opposite phenomenon was observed for copper. On the other hand, similar concentrations of joint $\mathrm{Zn}$ and Cu resulted to slight growth inhibition, indicating antagonism between the studied heavy metals. Experiments with the same microorganism at $20^{\circ} \mathrm{C}$ and $35^{\circ} \mathrm{C}$, at metal free and $10 \mu \mathrm{M} \mathrm{Zn}$, indicated that the stimulatory effect of zinc was significantly more pronounced at lower temperatures. The latter is indicative of the strong role of temperature on the expression of heavy metals to microorganisms.

Keywords: microorganisms, heavy metal, copper, zinc, temperature, batch reactor, Arthrobacter sp., joint toxicity, growth stimulation, growth inhibition

\section{Introduction}

Heavy metal contamination is a global environmental problem. The release of metals into the ecosystem either from naturally occurring sources or from anthropogenic activities poses a serious threat to public health due to their persistence, biomagnification and accumulation within the food chain. Arsenic, copper, cadmium, lead, chromium, nickel mercury and zinc are among the most commonly encountered heavy metals in polluted water (Kalavrouziotis et al., 2009). Although trace amounts of many heavy metals act as micronutrients to the microorganisms (Gikas and Romanos 2006; Burgess et al., 1999; Bruins et al., 2000), high concentrations are known to be toxic due to their interference with essential biochemical pathways (Nies, 1999). Metal availability, mobility, and hence, toxicity to aquatic microorganisms are strongly affected by the speciation of the heavy metals in water, soil and sediment systems (Tessier and Turner, 1995; Hagarova et al., 2012).

Microbial bioremediation has been emerged as an alternative technology to reduce heavy metal concentrations to acceptable levels in the ecosystem and enhance the removal of metals from aqueous systems (Groudev et al., 2010; Kumar et al., 2010). To understand the behavior of complex aquatic and biogeochemical ecosystems, it is vital to study effects of heavy metals to native microorganisms. Of primarily importance in the environmental detoxification process is the ability of certain microbial stains to tolerate increasing concentrations of heavy metals (Gikas, 2008). The latter process may affect the growth characteristics of the microorganisms and even the cellular morphology (Chakravarty and Şengör S.S. and Gikas P. (2014), The influence of single and combined effects of $\mathrm{Zn}, \mathrm{Cu}$ and temperature on microbial growth, Global NEST Journal, 16(4), 699-706. 
Banerjee 2008). Studies investigating such changes have been demonstrated for the acidophilic heterotroph Acidocella sp. GS19h strain (Chakravarty et al., 2007), for Acidiphilium symbioticum H8 (Chakravarty and Banerjee, 2008) and for Pseudomonas aeruginosa strain 4EA (Naik and Dubey, 2011), due to exposure to heavy metals. Besides morphological changes, reduction/adaptation of bacterial distribution, diversity and reduction enzyme expression profiles of various bacterial isolates due to the effect of heavy metals have recently been investigated (Jose et al., 2011).

Temperature is also a determined factor that affects the growth of microorganisms (Lee et al., 2011; Guo et al., 2010), as well as the toxicity of heavy metals (Cathum et al., 2005). Although biochemical reaction rates may roughly double with temperature increase by $10{ }^{\circ} \mathrm{C}$ (Rittman and McCarty 2001), microorganisms function at an optimum performance at a specific temperature range (Prescott et al., 2002). Temperature has been shown to affect the reduction rate of $\operatorname{Cr}(\mathrm{VI})$ (and hence chromium toxicity to Escherichia coli (Shen and Wang, 1994)), while in general, the optimum $\mathrm{Cr}(\mathrm{VI})$ resistance and reduction in microorganisms has been determined to be between $30-36{ }^{\circ} \mathrm{C}$ (Shen and Wang, 1994; Ishibachi et al., 1990; Wang and Xiao, 1995; Krauter et al., 1996; Vaiopoulou and Gikas 2012). Bioaccumulation of heavy metals has been determined to maximize at $25^{\circ} \mathrm{C}$ and $30{ }^{\circ} \mathrm{C}$ for $\mathrm{Cu}(\mathrm{II})$ and $\mathrm{Cd}(\mathrm{II})$, respectively, by Pseudomonas putida (Uslu et al., 2011) and at $30^{\circ} \mathrm{C}, 25^{\circ} \mathrm{C}$ and $30{ }^{\circ} \mathrm{C}$ for $\mathrm{Cd}(\mathrm{III}$ ), $\mathrm{Pb}(\mathrm{II})$ and $\mathrm{Cu}(\mathrm{II})$, respectively, by Rhizophus arrhizus (Uslu et al., 2003). On the other hand, a study on the effect of physical and physiological factors on heavy metal sorption by Bacillus subtilis and Bacillaceae sp. showed that a relatively high temperature $\left(45^{\circ} \mathrm{C}\right)$ was optimum for $\mathrm{Ag}(\mathrm{I}), \mathrm{Cr}(\mathrm{III})$ and $\mathrm{Pb}(\mathrm{II})$ sorption by the above bacterial strains (Fosso-Kankeu et al., 2010). Experiments conducted to examine the effect of heavy metal bioleaching by sulfur oxidation from sewage sludge has also been shown to highly depend on the process temperature, affecting the variation of growth rates of the bacterial species with $\mathrm{pH}$ (Tyagi et al., 1994). Activity of ammonia oxidizing bacteria (AOB) to simultaneous variations in $\mathrm{Zn}$ concentration, temperature $\left(23-33^{\circ} \mathrm{C}\right)$ and $\mathrm{AOB}$ concentration was studied by Lee et al. (Lee et al., 2011), where temperature was observed to have a significant effect on the lag time and ammonia oxidation rate at $A O B$ concentrations below $2.0 \times 10^{7}$ copies $/ \mathrm{mL}$.

While limited studies have focused on the impact of temperature on microorganisms under heavy metal exposure; to the authors' knowledge, the effects of temperature on the tolerance of microorganisms exposed to single and combined heavy metals have not yet been investigated. The individual and joint effects of $\mathrm{Zn}$ and $\mathrm{Cu}$ on the rate and extent of growth of a monoculture Artrobacter sp. JM018 (a heavy metal tolerant species) in a continuous flow reactor versus classical batch growth was reported by Sengor et al. (2012). In the present study, the effects of temperature on the individual and combined presence of $\mathrm{Zn}$ and $\mathrm{Cu}$ on the growth patterns of Arthrobacter sp. JM018 were tested using 1, 5, and 10 $\mu \mathrm{M} \mathrm{Zn}, \mathrm{Cu}$, and $1: 1 \mathrm{~mol} / \mathrm{mol}(\mathrm{Zn} / \mathrm{Cu})$ mixtures at $35^{\circ} \mathrm{C}$, in batch reactors. Comparative batch growth experiments were also conducted on Pseudomonas sp. and Arthrobacter sp. in the presence of metal free growth medium at $35^{\circ} \mathrm{C}$ and at ambient temperature $\left(20^{\circ} \mathrm{C}\right)$, and in the presence of $0.01 \mathrm{mM}$, $0.05 \mathrm{mM}$ and $0.1 \mathrm{mM} \mathrm{Zn}$ at $20{ }^{\circ} \mathrm{C}$. Microbes from the studied genera may exhibit relatively high tolerance to heavy metals as they have been isolated from a variety of heavy metal contaminated sites (Moberly et al., 2010; Zhang et al., 2004; Mongodin et al., 2006).

\section{Materials and methods}

\subsection{Microorganisms, growth media and inoculum preparation}

Arthrobacter sp. JM018 and Pseudomonas sp. were isolated from sediment samples from Coeur d'Alene River, Idaho, USA, where the site was contaminated with high levels of $\mathrm{Zn}$ ( $0.75 \%$ mass) and $\mathrm{Pb}$ (0.5\% mass) (Moberly et al., 2009; 2010) and provided a unique habitat for growth of heavy metal tolerant organisms. 16S rRNA gene clone-libraries and microarrays from the sediments samples taken at the time of collection indicated that Arthrobacter sp. were present in the microbial community (Moberly et al., 2010; Barua 2007). After isolation, Arthrobacter and Pseudomonas were grown on a modified formulation of metal toxicity medium (MTM) to decrease metal complexation and precipitation (Sani et al., 2001). The MTM was prepared by dissolving the following in one liter of distilled water: $0.9 \mathrm{~g}$, 
$\mathrm{C}_{6} \mathrm{H}_{12} \mathrm{O}_{6} ; 0.06 \mathrm{~g}, \mathrm{Na}_{2} \mathrm{SO}_{4} ; 0.02 \mathrm{~g}, \mathrm{NaHCO}_{3} ; 0.004 \mathrm{~g}, \mathrm{NaH}_{2} \mathrm{PO}_{4} ; 0.016 \mathrm{~g}, \mathrm{NH}_{4} \mathrm{Cl}$; and 0.02 g, yeast extract. Buffer capacity of the MTM was maintained with the addition of PIPES [piperazine- $N, \mathrm{~N}^{\prime}$-bis $(2-$ ethanesulfonic acid)], at a concentration of $1.73 \mathrm{~g}^{-1}$. The medium was autoclaved in serum bottles for sterilization before inoculation. Stock solutions of $10 \mathrm{mM} \mathrm{ZnCl}_{2}$ and $10 \mathrm{mM} \mathrm{CuCl}_{2}$ were prepared in deionized water and acidified with 3 drops of concentrated hydrochloric acid to $\mathrm{pH} 1.5$, and filtered through $0.2 \mu \mathrm{m}$ membrane filter for sterilization (autoclave of heavy metal solution was avoided to prevent complexation or precipitation at high temperature and keep the solution stable with time). A $5 \%$ by volume inoculum was taken from batch cultures unexposed to metals from the late exponential/early stationary cell growth phase. Cell growth was monitored by measuring optical density (O.D.) at $600 \mathrm{~nm}$ using a Genesys ${ }^{\mathrm{TM}} 10$ Series Spectrophotometer (Thermo Electron Corporation).

\subsection{Batch Experiments}

Batch experiments were conducted in duplicates and under sterile conditions in $500 \mathrm{~mL}$ serum bottles sealed with butyl rubber septa. $100 \mathrm{~mL}$ of medium was added in each bottle and autoclaved at $121{ }^{\circ} \mathrm{C}$ for $20 \mathrm{~min}$. After cooling to $25^{\circ} \mathrm{C}, 5 \% \mathrm{v} / \mathrm{v}$ inoculum was added. Serum bottles were supplemented with filter sterilized $(0.2 \mu \mathrm{m}) \mathrm{Cu}$ or $\mathrm{Zn}$ stock solutions to give final (single and combined) concentrations of 1 , 5 and $10 \mu \mathrm{M}$ of $\mathrm{Zn}$ and/or $\mathrm{Cu}$. Serum bottles were incubated at 20 or $35{ }^{\circ} \mathrm{C}$ and where continuously shaken at $100 \mathrm{rpm}$. Samples were taken at regular intervals for cell growth (O.D. at $600 \mathrm{~nm}$ ) and metals analyses. Microbial growth was monitored by measuring the O.D. of each sample withdrawn at regular intervals from the reactors. Zinc and copper concentrations were monitored using the U.S. Environmental Protection Agency approved colorimetric ZincoVer ${ }^{\circ}$ reagent method $(620 \mathrm{~nm})$ (Hach Method 8009 (Sani et al., 2003); and porphyrin method (Hach Method 8506, Loveland, Co Sani et al., 2001). Calibration standards for both metals were prepared from serially diluted stock solutions of 10 $\mathrm{mM} \mathrm{ZnCl} 2$ and $10 \mathrm{mM} \mathrm{CuCl}_{2}$. Triplicate samples were obtained for O.D. and heavy metal concentration measurements. Theoretical limits of quantification were 0.75 and $0.2 \mu \mathrm{M}$ for $\mathrm{Zn}$ and $\mathrm{Cu}$, respectively. The Student's $t$-distribution, with a 0.05 level of significance, was employed to reject the statistically extreme values of O.D. and heavy metal concentrations.

\section{Results and discussion}

\subsection{Exposure of Arthrobacter sp. to Zn and Cu at $35^{\circ} \mathrm{C}$}

Figure 1 shows changes in O.D. (at $600 \mathrm{~nm}$ ) with incubation time for Arthrobacter sp. JM018 grown at $35{ }^{\circ} \mathrm{C}$, under batch conditions, at single 1,5 , and $10 \mu \mathrm{M} \mathrm{Zn}$ and $\mathrm{Cu}$ concentrations, and under combinations of $1 / 1,5 / 5$, and $10 / 10 \mu \mathrm{MCu} / \mu \mathrm{MZn}$ respectively. The corresponding maximum specific growth rates have been calculated and shown in Figure2. According to the data presented in Figure 2, zing stimulated the growth of Arthrobacter at all studied concentrations, however the stimulation effect was decreased from $19 \%$, at $1 \mu \mathrm{M} \mathrm{Zn}$, to $2 \%$, at $10 \mu \mathrm{M} \mathrm{Zn}$ concentration. Exposure of Arthrobacter sp. JM018 to 50, 100 and $150 \mu M$ Zn concentrations has been studied by Sengor et al. (2012), where all of the $\mathrm{Zn}$ concentrations tested in this range showed an increasing stimulation with increasing $\mathrm{Zn}$ concentration. The difference in this observed stimulation effects may be due to the effect of $35{ }^{\circ} \mathrm{C}$ cultivation temperature, compared to room temperature $\left(23^{\circ} \mathrm{C}\right)$ in the previous study(Sengor et al., 2012), as the same growth medium and conditions were used in both studies for the same bacterial species. On the other hand, the response of Arthrobacter sp. JM018 to 0-250 $\mu \mathrm{M} \mathrm{Zn}$ at pH range between 6-8 studied by Moberly et al. (2010), showed inhibition, with an exception of a small stimulatory effect at $\mathrm{pH} 6$ and $10 \mu \mathrm{M} \mathrm{Zn}$. The observed differences could be due to the cultivation temperature or due to differences in the organic substrate and possibly to the inoculum history. Apart from Arthrobacter sp., stimulatory effect of $\mathrm{Zn}$ have also been observed for the growth of activated sludge up to $40 \mathrm{mg} \mathrm{l}^{-1}(610 \mu \mathrm{M}) \mathrm{Zn}$ (Lin et al., 2003) and for $1 \mathrm{mg} \mathrm{l}^{-1}(15 \mu \mathrm{M}) \mathrm{Zn}$ (Cabrero et al., 1998); and for the growth of Shewanella isolates MB4 and FB 18 for up to $25 \mu \mathrm{M} \mathrm{Zn}$ (Toes et al., 2008). 


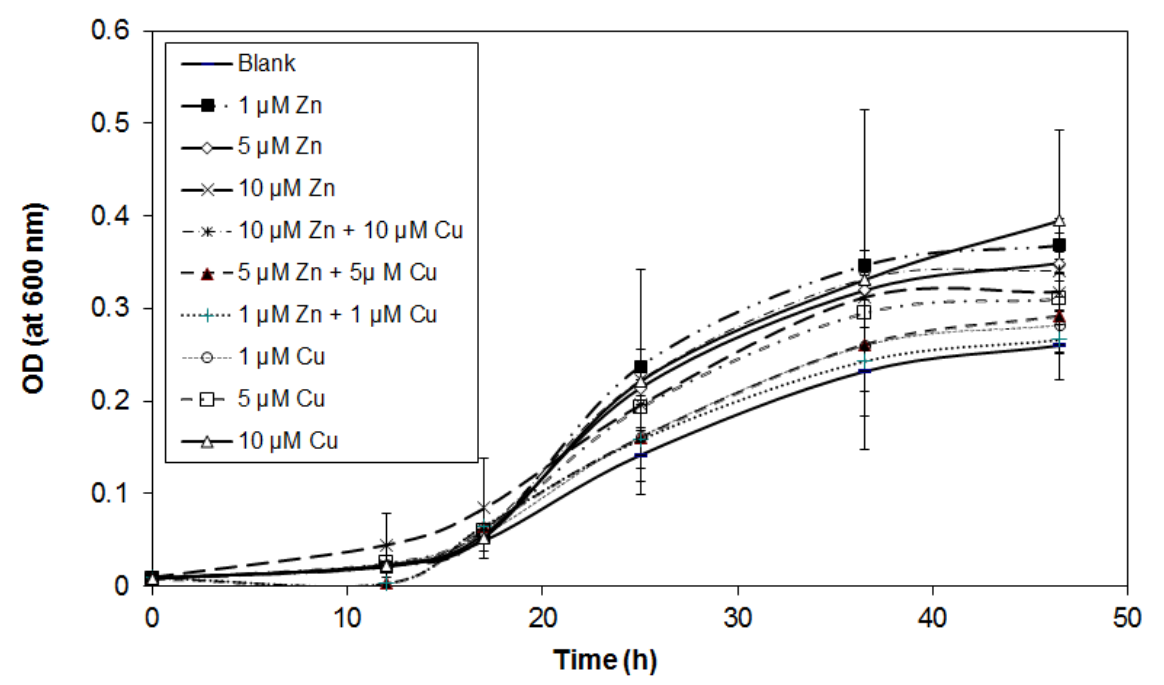

Figure 1. Optical density versus incubation time for Arthrobacter sp. growing under batch conditions at metal free, and at the presence of single 1,5 , and $10 \mu \mathrm{M} \mathrm{Zn}$ and $\mathrm{Cu}$ concentrations, and under $1 / 1,5 / 5$, and $10 / 10 \mu \mathrm{MCu} / \mu \mathrm{MZn}$ combinations at $35^{\circ} \mathrm{C}$. Error bars are $95 \%$ confidence intervals.

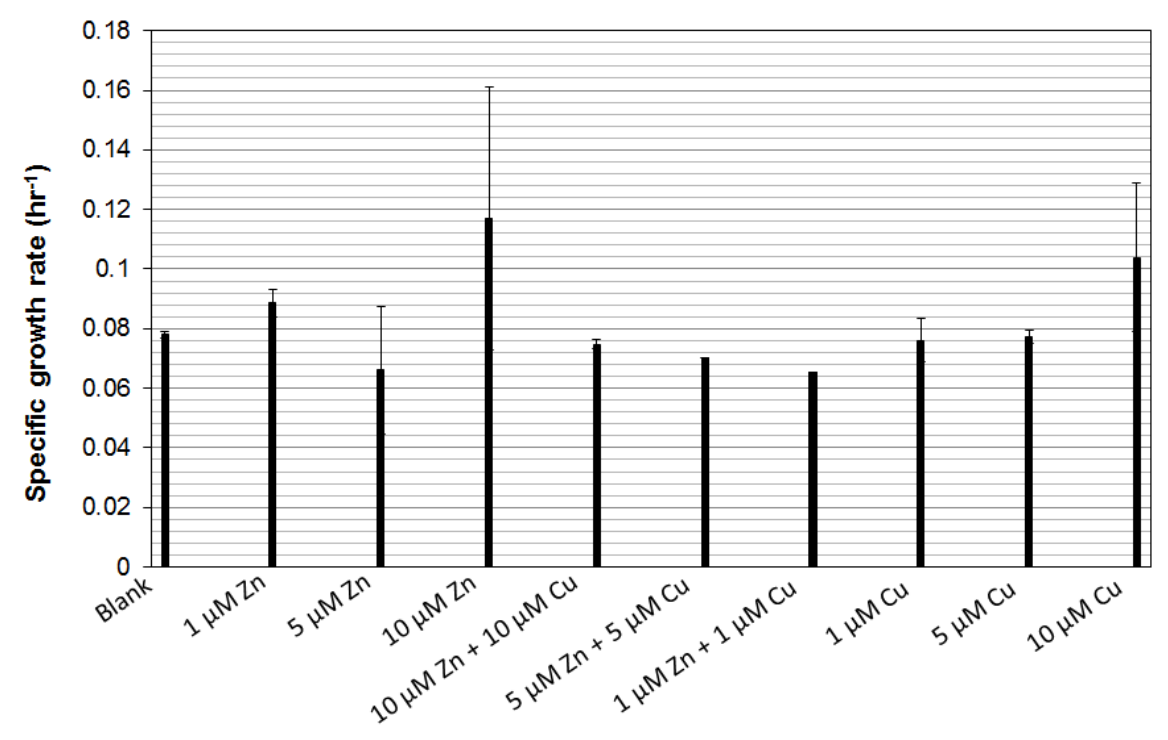

Figure 2. Specific growth rates $\left(\mathrm{h}^{-1}\right)$ of Arthrobacter sp., to metal free, and to the presence of single 1, 5, and $10 \mu \mathrm{M} \mathrm{Zn}$ and $\mathrm{Cu}$ concentrations, and to $1 / 1,5 / 5$, and $10 / 10 \mu \mathrm{MCu} / \mu \mathrm{MZn}$ combinations at $35^{\circ} \mathrm{C}$.

Error bars are $95 \%$ confidence intervals.

Based on the present data, addition of copper resulted to growth stimulation of Arthrobacter with maximum stimulation of $20 \%$ at $10 \mu \mathrm{M} \mathrm{Cu}$. Similar stimulatory effects of $\mathrm{Cu}$ have also been observed for exopolyphosphatase (PPX) activity of $A$. ferrooxidans up to $1-2 \mu \mathrm{M} \mathrm{Cu}$, where inhibition in the PXX activity occurred for $\mathrm{Cu}$ concentrations greater than $5 \mu \mathrm{M}$ (Alvarez and Jerez, 2004), and up to $10 \mu \mathrm{M} \mathrm{Cu}$ for the archaeon Sulfolobus metallicus (Remonsellez et al., 2006). $\mathrm{Zn}$ was also observed to stimulate the PXX activity of $A$. ferrooxidans at 1-2 $\mu \mathrm{M}$ concentrations; however, this stimulation effect was only half compared to that of exposure to $\mathrm{Cu}$ (Alvarez and Jerez, 2004). Stimulation effect of Zn on the PXX activity was also seen for $S$. metallicus in the micromolar range, similarly lower than of the Cu effect (Remonsellez et al., 2006), both consistent with our observations with Arthrobacter sp. Stimulation by $\mathrm{Cu}$ was also observed for the superoxide dismutase (SOD) activity of the strain $\mathrm{N} 6$ of the yeast Cryptococcus sp. when the cells were grown in the presence of $10 \mathrm{mM} \mathrm{CuSO}_{4}$, and the stimulation effect was remarkably enhanced in the presence of $10 \mathrm{mM} \mathrm{CuSO}_{4}$ (Abe et al., 2001). 
On the other hand, addition of mixture of zinc and copper resulted to slight growth inhibition, which was measured to vary between $2 \%$, at $10 \mu \mathrm{M} \mathrm{Zn}+10 \mu \mathrm{M} \mathrm{Cu}$, to $15 \%$, at $1 \mu \mathrm{M} \mathrm{Zn}+10 \mu \mathrm{M} \mathrm{Cu}$. From the collected data, it looks that zinc and copper have a strong antagonistic effect to the growth of Arhtrobacter, as the phenomenon is reversed from growth stimulation at the presence of single $\mathrm{Zn}$ or $\mathrm{Cu}$ to growth inhibition at joint presence of both metals. However, it should be taken into account that the total concentration of metals $(\mathrm{Zn}+\mathrm{Cu})$ was double in the case of joint concentrations, and this may be one of the reasons for the observed growth inhibition.

\subsection{Exposure of Arthrobacter sp. to Zn at 20 and $35^{\circ} \mathrm{C}$}

Growth curves and specific growth rates for Arthrobacter sp. growing in the presence of metal free growth media at $35^{\circ} \mathrm{C}$ and $20^{\circ} \mathrm{C}$, and in the presence of $10 \mu \mathrm{M} \mathrm{Zn}$ at the same temperatures are shown in Figure 3. The relative specific growth rates are shown in Figure 4. A significant increase of $92 \%$ of specific growth rate for Arthrobacter is observed with the increase of temperature form 20 to $35^{\circ} \mathrm{C}$. On the other hand, the stimulatory effects of zinc to the growth of Arthrobacter are obviously more pronounced at $20^{\circ} \mathrm{C}$, compared with $35^{\circ} \mathrm{C}$, as in the first case it is observed stimulation by $61 \%$ at $10 \mu \mathrm{M}$ $\mathrm{Zn}$, while in the second case the same concentration of zinc has almost inert effect to growth. Temperature may have significant influence over the function and cell structure of the microorganisms, where higher temperature, up to an optimum value, would increase the metabolic activity and energy of the system (Prescott et al., 2002), perhaps promoting the stimulation effect of the heavy metal. FossoKankeu et al. (2010) observed higher removal efficiency of $\mathrm{Ag}(\mathrm{I}), \mathrm{Cr}(\mathrm{III})$ and $\mathrm{Pb}(\mathrm{II})$ from aqueous solutions at a higher temperature $\left(45^{\circ} \mathrm{C}\right)$ irrespectively of the type of the studied microorganism. The latter is similar to the trend observed by Goyal et al. (2003) for biosorption of $\mathrm{Cr}(\mathrm{VI})$ by Saccharomyces cerevisae. Although Fosso-Kankeu et al. (2010) showed a positive correlation between temperature increase and heavy metal biosorption, the degree of variation of the metal uptake was different among various heavy metals. However, in our study we have observed that zinc stimulation is more pronounced at lower temperatures.

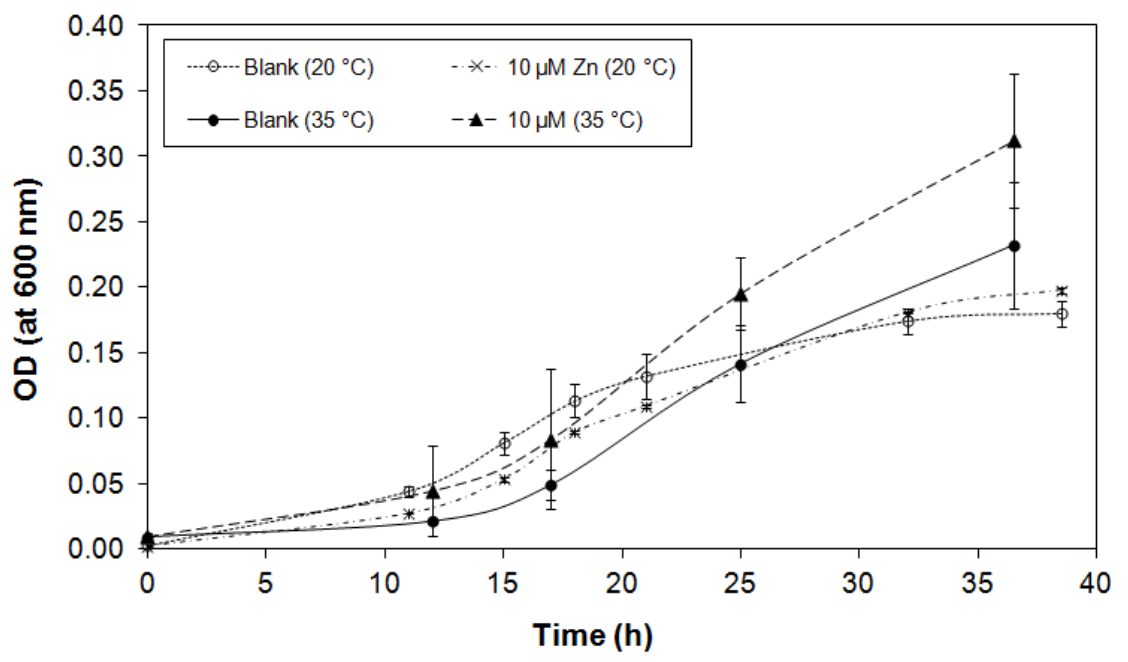

Figure 3. Optical density versus incubation time for Arthrobacter sp. growing in the presence of metal free growth medium and in the presence of $10 \mu \mathrm{M}$ at $35 \stackrel{\circ}{\circ}$ and at $20 \stackrel{\circ}{C}$ at metal free and in the presence of $10 \mu \mathrm{M} \mathrm{Zn}$. Error bars are $95 \%$ confidence intervals.

Comparative batch growth experiments were also conducted for Pseudomonas sp. For the Pseudomonas, the microbial yields also showed higher growth at metal-free medium at $35^{\circ} \mathrm{C}$, followed by the metal-free medium at $20^{\circ} \mathrm{C}$ and by $10 \mu \mathrm{M} \mathrm{Zn}$ at $20^{\circ} \mathrm{C}$ (data not shown). The growth curves showed that there was increase of lag time from 8 and 15 hours between growth at metal-free (at $20^{\circ} \mathrm{C}$ ) and at $10 \mu \mathrm{M} \mathrm{Zn}$ concentration (at $20^{\circ} \mathrm{C}$ ), respectively, whereas at metal free growth at $35^{\circ} \mathrm{C}$ the lag time was observed to be zero (Gikas et al., 2009). Increase in lag time with the decrease in 
temperature has also been observed by Lee et al. (2011) for the activity of ammonia oxidizing bacteria. The latter may be attributed to the fact that the biochemical reactions are accelerated until an optimum temperature value (Prescott et al., 2002), which may reduce the lag time required for the synthesis of enzymes, substrates, acclimation to the heavy metals, etc. prior to the start of the succeeding phase. The latter results, comparing the growth behavior of the two bacterial monocultures (Pseudomonas sp., Arthrobacter sp.) tested under these concentration ranges of $\mathrm{Zn}$, possibly indicates different mechanisms of $\mathrm{Zn}$ toxicity by the two microbial species

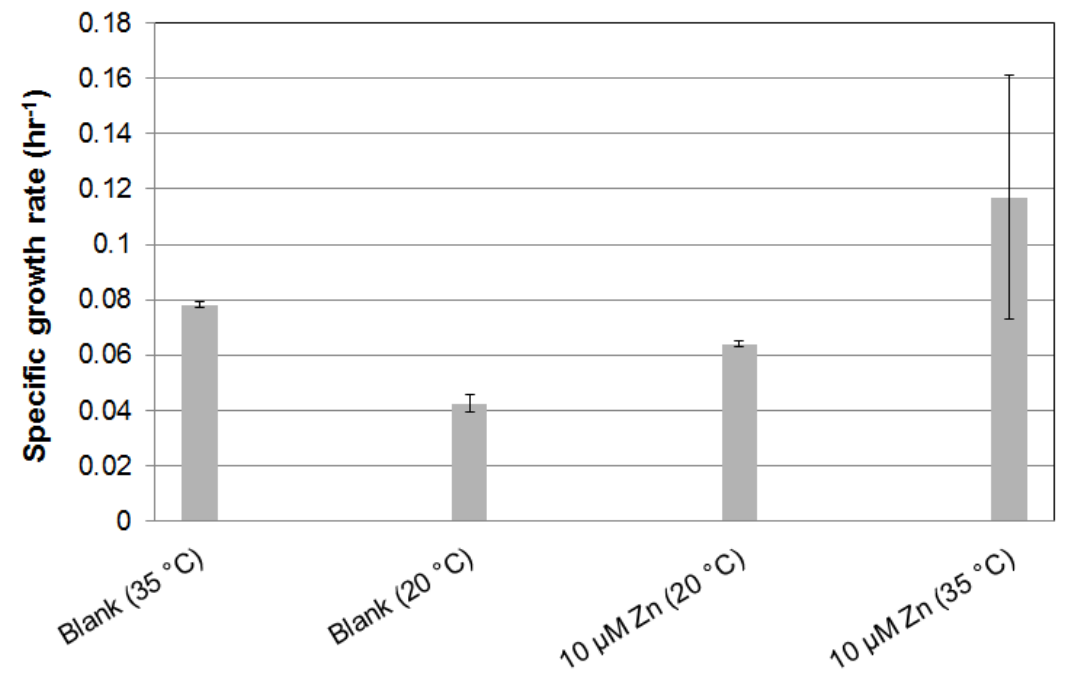

Figure 4. Specific growth rate $\left(\mathrm{h}^{-1}\right)$ of Arthrobacter sp., at metal free growth medium at $35^{\circ} \mathrm{C}$ and $20^{\circ} \mathrm{C}$, and at $10 \mu \mathrm{M} \mathrm{Zn}$ at $35{ }^{\circ} \mathrm{C}$ and $20^{\circ} \mathrm{C}$. Error bars are $95 \%$ confidence intervals.

\section{Conclusions}

In the present study, batch tests were carried out to evaluate the individual and combined effects of $\mathrm{Zn}$ and $\mathrm{Cu}$ on the growth patterns of Arthrobacter sp. JM018 at $35^{\circ} \mathrm{C}$. The results showed that in all of the $\mathrm{Zn}$ and $\mathrm{Cu}$ concentrations exhibited a stimulatory effect on JM018 growth; however, the stimulatory effects of zinc were faded out with the increase of $Z n$ concentration from $1 \mu \mathrm{M}$ to $10 \mu \mathrm{M}$, while the opposite phenomenon was observed for copper. On the other hand, joint concentrations of $\mathrm{Zn}$ and $\mathrm{Cu}$ resulted to growth inhibition. Experiments with Arthrobacter growth at different temperatures with and without the presence of zinc, indicated that the stimulatory effects of zinc was significantly higher at lower temperatures. The latter is indicative of the strong role of temperature on the expression of heavy metals to microorganisms.

\section{References}

Abe F., Miura T., Nagahama T., Inoue A., Usami R. and Horikoshi K. (2001), Isolation of highly copper-tolerant yeast, Cryptococcus sp., from the Japan Trench and the induction of superoxide dismutase activity by $\mathrm{Cu}_{2}{ }^{+}$, Biotechnol Lett, 23, 2027-2034.

Alvarez S. and Jerez C. (2004), Copper ions stimulate polyphosphate degradation and phosphate efflux in Acidithiobacillus ferrooxidans, Appl Environ Microbiol, 70, 5177-5182.

Barua S. (2007), Microbial Diversity and Zinc Toxicity to Pseudomonas sp. from Coeur d'Alene River Sediments, Master's Thesis, Montana State University, Bozeman.

Bruins M.R., Kapil S. and Oehme F.W. (2000), Microbial resistance to metals in the environment, Ecotoxicol Environ Safety, 45, 198-207. 
Burgess J.E., Quarmby .J and Stephenson T. (1999), Role of micronutrients in activated sludge-based biotreatment of industrial effluents, Biotechnol Adv, 17, 49-70.

Cabrero A., Fernandez S., Mirada F. and Garcia J. (1998), Effects of copper and zinc on the activated sludge bacteria growth kinetics, Water Res 32, 1355-1362.

Cathum S., Velicogna D., Obenauf A., Dumouchel A., Punt M., Brown C.E. and Ridal, J. (2005), Detoxification of mercury in the environment, Anal Bioanal Chem, 381, 1491-1498.

Chakravarty R. and Banerjee P.C. (2008), Morphological changes in an acidophilic bacterium induced by heavy metals, Extremophiles, 12, 279-284.

Chakravarty R., Manna S., Ghosh A.K. and Banerjee P.C. (2007), Morphological changes in an Acidocella strain in response to heavy metal stress, Res J Microbiol, 2, 742- 748.

Fosso-Kankeu E., Mulaba-Bafubiandi A.F., Mamba B.B., Marjanovic L. and Barnard T.G. (2010), A comprehensive study of physical and physiological parameters that affect bio-sorption of metal pollutants from aqueous solutions, Phys Chem Earth, 35, 672-678.

Gikas P. (2008), Single and combined effects of nickel (Ni(II)) and cobalt (Co(II)) ions on activated sludge and on other aerobic microorganisms : A review, J Hazard Mater, 159, 187-203.

Gikas P. and Romanos P. (2006), Effects of tri-valent $\left(\mathrm{Cr}^{(\mathrm{III})}\right)$ and hexa-valent $\left(\mathrm{Cr}^{(\mathrm{VI})}\right)$ chromium on the growth rate of activated sludge, J Hazard Mater B 133, 212-217.

Gikas P., Şengör S.S., Ginn T.R., Moberly J. and Peyton B.M. (2009), The effects of heavy metals and temperature on microbial growth and lag, Global Nest Journal, 1(3), 325-332.

Goyal N., Jain S.C. and Banerjee U.C. (2003), Comparative studies of the microbial adsorption of heavy metals, Adv Environ Res, 7, 311-319.

Groudev S., Spasova I., Nicolova M. and Georgiev P. (2010), In situ bioremediation of contaminated soils in uranium deposits, Hydrometallurgy, 104, 518-523.

Guo J., Peng Y., Huang H., Wang S., Ge S., Zhang J. and Wang, Z. (2010), Shorthand long-term effects of temperature on partial nitrification in a sequencing batch reactor treating domestic wastewater, J Hazar Mater, 179, 471-479.

Hagarova I., Machackova L., Zemberyova M. and Navojova V. (2012), Determination of beryllium in various types of natural waters by electrothermal atomic absorption spectrometry, Global Nest Journal, 14(1), 40-47.

Ishibashi Y., Cervantes C. and Silver S. (1990), Chromium reduction in Pseudomonas putida, Applied and Environmental Microbiology, 56, 2268-2270.

Jose J., Giridhar R., Anas A., Bharathi P.A.L. and Nair S. (2011), Heavy metal pollution exerts reduction/adaptation in the diversity and enzyme expression profile of heterotrophic bacteria in Cochin estuary, Environ Pollut, 159, 2775-2780.

Kalavrouziotis I.K., Koukoulakis P.H. and Papadopoulos A.H. (2009), Heavy metal interrelationships in soil in the presence of treated wastewater, Global Nest Journal, 11(4), 497-509.

Krauter P., Martinelli R., Williams K. and Martins S. (1996), Removal of Cr(VI) from ground water by Saccharomyces cerevisiae, Biodegradation, 7, 277-286.

Kumar A., Bisht B.S. and Joshi V.D. (2010), Biosorption of Heavy Metals by four acclimated microbial species, Bacillus spp., Pseudomonas spp., Staphylococcus spp. and Aspergillus niger, J Biol Environ Sci, 4, 97-108.

Lee S., Cho K., Lim J., Kim W. and Hwang S. (2011), Acclimation and activity of ammonia-oxidizing bacteria with respect to variations in zinc concentration, temperature, and microbial population, Bioresource Technology, 102, 4196-4203.

Lin Y., Yang X. and Liu Y. (2003), Kinetic responses of activated sludge microorganisms to individual and joint copper and zinc, J Environ Sci Health Part A: Environ Sci Eng A, 38, 353-360.

Moberly J., Borch T., Sani R., Spycher N., Şengör S.S, Ginn T. and Peyton B.M. (2009), Heavy Metal-Mineral Associations in Coeur d'Alene River Sediments: A Synchrotron-Based Analysis, Water Air Soil Pollut, 201, 195-208.

Moberly J.G., Staven A., Sani R.K. and Peyton B.M. (2010), Influence of pH and inorganic phosphate on toxicity of zinc to Arthrobacter sp. isolated from heavy-metal-contaminated sediments, Environ Sci Technol, 44, 7302-7308. 
Mongodin E.F., Shapir N., Daugherty S.C., Deboy R.T., Emerson J.B., Shvartzbeyn A., Radune D., Vamathevan J., Riggs F., Grinberg V., Khouri H., Wackett L.P., Nelson K.E. and Sadowsky M.J. (2006), Secrets of soil survival revealed by the genome sequence of Arthrobacter aurescens TC1, PLoS Genet, 2, 2094-2106.

Naik M.M. and Dubey S.K. (2011), Lead-Enhanced Siderophore Production and Alteration in Cell Morphology in a $\mathrm{Pb}$-Resistant Pseudomonas aeruginosa Strain 4EA, Curr Microbiol, 62, 409-414.

Nies D.H. (1999) Microbial heavy-metal resistance, Appl Microbiol Biotechnol, 51, 730-750.

Prescott L.M., Harley J.P. and Klein D.A. (2002), Microbiology. $5^{\text {th }}$ ed., US: McGraw-Hill Higher Education, New York.

Remonsellez F., Orell A. and Jerez C.A. (2006), Copper tolerance of the thermoacidophilic archaeon Sulfolobus metallicus: possible role of polyphosphate metabolism, Microbiology, 152, 59-66.

Rittmann B.E. and McCarty P.L. (2001), Environmental Biotechnology: Principles and Applications, McGraw-Hill, New York, NY.

Sani R.K., Geesey G. and Peyton B.M. (2001), Assessment of lead toxicity to Desulfovibrio desulfuricans G20: influence of components of Lactate C medium, Adv Environ Res, 5, 269-276.

Sani R.K., Peyton B. and Jandhyala M. (2003), Toxicity of lead in aqueous medium to Desulfovibrio desulfuricanis G20, Environ Toxicol Chem, 22, 252-260.

Sani R.K., Peyton B.M. and Brown L.T. (2001), Copper induced inhibition of growth of Desulfovibrio desulfuricans G20: Assessment of its toxicity and correlation with those of zinc and lead, Appl Environ Microbiol, 67, 4765-4772.

Şengör S.S., Gikas P., Moberly J.G., Peyton B. and Ginn T.R. (2012), Comparison of single and joint effects of Zn and $\mathrm{Cu}$ in continuous flow and batch reactors, J Chem Technol Biotechnol, 87, 374-380.

Shen H. and Wang Y-T, (1994), Biological reduction of chromium by E. coli, Journal of Environmental Engineering, 120, 560-572.

Tessier A.and Turner D.R. (1995), Metal speciation and bioavailability in aquatic systems; John Wiley and Sons, Chichester.

Toes A.C.M., Finke N., Kuenen J.G. and Muyzer G. (2008), Effects of deposition of heavy-metal-polluted harbor mud on microbial diversity and metal resistance in sandy marine sediments, Arch Environ Contam Toxicol, 55, 372-385.

Tyagi R.D., Sreekrishnan T.R., Blais J.F. and Campbell G.C. (1994), Heavy metal bioleaching from sewage sludge-ill: Temperature effects, Water Res, 28, 2367-2375.

Uslu G., Dursun A.Y., Ekiz H.i. and Aksu Z. (2003), The effect of Cd (II), Pb (II) and Cu (II) ions on the growth and bioaccumulation properties of Rhizopus arrhizus, Process Biochemistry, 39, 105-110.

Uslu G., Gultekin G. and Tanyol M. (2011), Bioaccumulation of copper (II) and cadmium (II) from aqueous solution by Pseudomonas putida nrrl b-252, Fresenius Environ Bull, 20, 1812-1820.

Vaiopoulou E. and Gikas P. (2012), Effects of chromium on activated sludge and on the performance of wastewater treatment plants: A review, Wat Res, 46, 549-570.

Wang Y-T. and Xiao C. (1995), Factors affecting hexavalent chromium reduction in pure cultures of bacteria, Wat Res, 29, 2467-2474.

Zhang H., Duan C., Shao Q., Ren W., Sha T., Cheng L., Zhao Z., and Bin H. (2004), Genetic and physiological diversity of phylogenetically and geographically distinct groups of Arthrobacter isolated from lead zinc mine tailings, FEMS Microbiol Ecol, 49, 333-341. 